\title{
Smart City Concept Of Merauke Regency In Provinding Information Public Service Considering Of Local Wisdoms
}

\author{
Fitriani $^{1}$, Fransin Kontu ${ }^{1}$, Vinsenco A. Serano ${ }^{1}$, Imelda C. laode ${ }^{1}$, Albert Maturan ${ }^{1}$, Edoardus E. Maturbongs ${ }^{1}$, Hubertus \\ $\mathrm{Oja}^{1}$, and Hesty Tambajong ${ }^{1}$. \\ ${ }^{1}$ Departement Science of public administration, Faculty of Social Science and Political Science, Musamus University, Merauke - Papua \\ - Indonesia.
}

\begin{abstract}
The goal of Smart City's implementation is to establish and implement a safe, secure, controlled city and facilitate access for its citizens and strengthen the city's economic, social and technological competitiveness. Merauke includes a city full of cultural richness and high tourism potential, so if not anticipated earlier it will diminish all the potential that exists. In order to realize Merauke Smart City is needed support multistakeholders participation, intelligent community with equality and good education, sustainable and integrated strategic plan, and partnerships. The recommendation of this review is the need for a roadmap as a guide for the development of cultural ecosystems and digital-based Merauke tourism and the need for specialized institutions that manage IT and information and its human resources in management.
\end{abstract}

Keywords: smart city; information system; public services

\section{Introduction}

Simply a smart regency is a Regency whose Regency's management system is automatically able to notify: (1) that a Regency problem arises (notified by censorship in the Regency), (2) that a (notified by censors and prediction systems), and (3) the Regency management system is capable of providing automatic action proposals (made possible by the actuator system) or non-automatic to solve problems [1]. Carragliu et al [2] states that the Regency will be smart if investments in human resources, social capital and infrastructure of traditional and modern communications systems can promote sustainable economic growth and quality of life by prudent management of natural resources, through participatory governance. In addition, [3] divides smart city into 6 dimensions, namely: (1) Smart economy; (2) Smart mobility; (3) Smart environment; (4) Smart people; (5) Smart living; and (6) Smart governance, in which each dimension is broken down into several indicators. As for Djunaedi [1] add one more dimension related smart city, that is smart disaster management related to the location of the Indonesian state that is in the ring of fire.

The purpose of Smart City's implementation is to establish and implement a safe, convenient, controlled Regency and facilitate access for its citizens and strengthen the competitiveness of the Regency in economic, social and technological matters. So it can be explained that the purpose of the Smart City implementation strategy is to

support the Regency within the social dimension (security), economy (competitiveness), technology and environment (comfort). Or more generally based on the United Nations, it can be said that Smart City's goal is to establish a Regency Sustainable (economic, social, environmental). Implementation of the concept of smart city is also supported by applications that continue to grow so as to create a creative environment in the field of technology, as a good first step towards smart Regency.

Merauke Regency is one of the Regencys of Papua Province that has the potential and enables to apply the concept of smart city. Some of the basic capital possessed by Merauke Regency are among others the cultural capital which is timeless due to the changing times, social capital and local wisdoms and human capital, Creative and Innovative, Egalitarian and high tolerance, Merauke is also known as a liveable city. Merauke Regency has conducted assessment, comparative study, training and in 2016 has officially cooperated with Bandung Regency Government to develop Smart City technology in Meruake Regency. Where Bandung Regency Government already has a superior application, namely Bandung Integrated Resources Management System (BIRMS) which is an innovation to make the whole bureaucratic affairs integrated in information technology (IT). On August 25, 2016, the Government of Merauke Regency received 
the Smart City Nusantara (SCN) Award, awarded by PT Telkom Indonesia. The award received by Merauke Regency can not be separated from the rapid assessment of Information Technology progress in Merauke. Regency-level Internet usage has been spread evenly in all SKPD with total users to date as many as 1400 personnel both ASN and Honorer. If the Papua New Government launched a free Internet Launch (2016), Merauke Regency has already launched in 2015 and then through FREEHOTSPOT program http://freehotspot.merauke.go.id/ with total number of users of the general public as many as 16,188 users. Hotspot point is currently located at 3 points namely in Taman Mandala, Libra Park and Office of Communications and Information Technology / Market Wamanggu. The local government unit of Merauke Regency has been simultaneously built since 2012 to date using.

\section{Method}

The methods this Study are with literature studies to find out the indicators on Smart City Readiness. After the determination of indicators and benchmarks for Smart City conducted a survey of required data, the processing of survey data and conducted analysis and conclude the current conditions.

\section{Literature Review}

Smart City Concept is the concept of smart Regency or better known as smart city is very popularly developed as one of the concept of arrangement of the Regencys in the world in recent years along with the rapid development of technology. It was in 2005 that the development of intelcities shifted into smartcities by emphasizing the next level of intelligence such as intelligence at meetings, networks, innovations, creativity, modernity, inclusiveness and social capital with the latest embodiment of sustainable communities. From the development called [4] above, it appears that the development of technology is undeniably one of the important determinants in the development of the concept of smart city. More comprehensive, [5] technology is not the only factor in smart city. There are still 2 (two) other factors namely institutional factors and human factors as a supporter of the growth and development of the concept of smart city. Inevitably, the views [5] are widely used by Regency governments, Regency managers and parties involved in developing the concept of smart city and applying it From the socalled development in the Regencys of the world.

Implementation of the concept of smart city in Regency planning is to realize sustainable development by improving public services by integrating several elements in the regencies such as governance, economy, quality of life, environment, human resources, and transportation. Any 6 (six) dimensions in the concept of smart city as the basis of smart city application which is then used in calculating smart city index 70 (seventy)
Regencys in Europe [6]. This Indicators used as a process of assessment of the Regencys that have applied the concept of smart city. European Smart Cities (www.smart-cities.eu) ranks any medium size regencies that have met six smart city criteria: smart economy, smart people, smart government, smart mobility, smart environment and smart living.

\section{Discussion}

The Government of Merauke Regency is still in the stage of building infrastructure that supports Merauke Towards Smartcity, one of which is by making Smart City website which in it provides information to the community, and providing application training and comparative study to Regencys that have successfully implemented Smartcity.

The authors offer a framework of Smart City concept of Merauke Regency that is offered is to be "Regency Education, Agriculture and Tourism, Based Local Wisdom ". The basic concept has 4 (four) keywords namely tourism, education, agriculture and local wisdom. These four keywords will be developed as a smart city development destination in Merauke Regency, with the main umbrella of smart local wisdom. If further elaborated, smart tourism; smart education; smart culture; smart local wisdom is 4 (four) main objectives of smart city of Merauke that can be achieved through the implementation of 7 (seven) smart service indicator that is smart environment, smart mobility, smart government, smart economy, smart people, smart living and smart disaster management. The concept of smart city of Merauke Regency can be seen in the picture below:

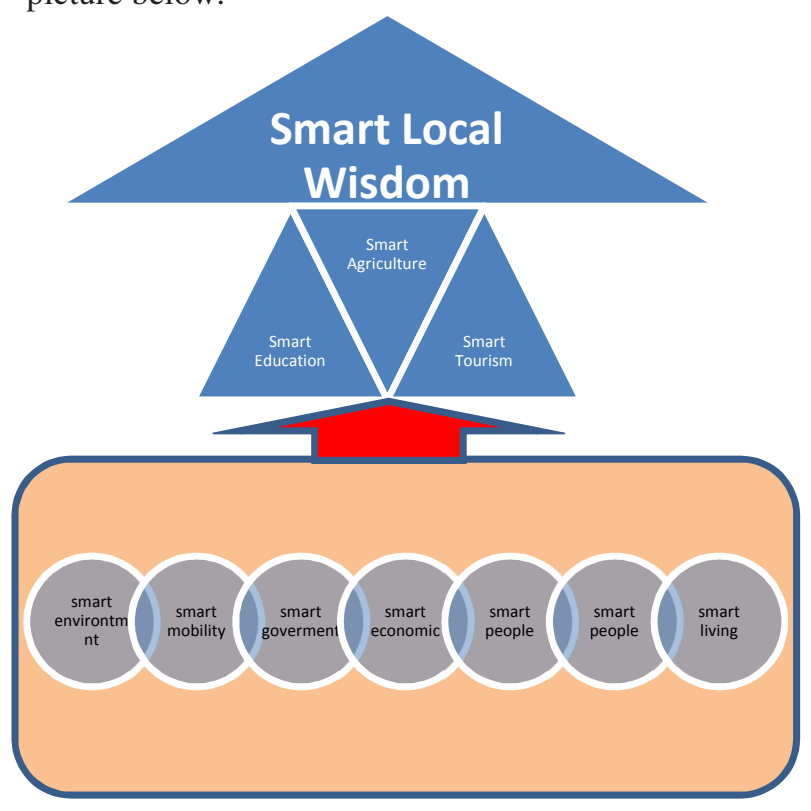

Fig 1 . The concept of smart city of Merauke

The main goal of Smart City Merauke can be achieved if the achievement indicators of smart local wisdom dimension, smart agriculture, smart tourism, and smart education are fulfilled. (1) Smart agriculture has the main achievement indicator that is the realization 
of national rice granary. Meanwhile, (2) smart tourism has 3 (three) indicators to be achieved that is the number of tourists, length of stay (length of stay), and the amount of money spent (spent money). The last one is (3) smart education with 3 (three) main achievement indicators that are quality, access, and educational related infrastructures. All indicators will be based on local wisdom. Smart city development and development need to pay attention to application infrastructure; human Resources; network infrastructure; information infrastructure, network integration, information and applications; funding; organizational structure, management system and work process; maintenance (maintenance); regulation, stages of e-Government development, stages of infrastructure development, stages of e-Government implementation, stages of development and / or development of support systems; and change management.

Smartcity infrastructure must meet Service Level Agreement (SLA) on network management aspects including network aviability, back-up system / redundancy system, network security, and network reliability. The information presented by various smart city applications must comply with privacy / confidentiality, integrity, authentication, availability, non-repudiation, and access control / access control). Concepts and frameworks in this smart city roadmap in Merauke Regency should be flexible or may change over the next several years, due to the influence of technological advances. This smart city Road Map can be used as input or input to the RPJMD (Regional Medium Term Development Plan).

Components of learning play an important role in the realization of smart city, so the need for 'living labs Merauke smart city' to support the development of information about smart city. Living Lab Smart City partners with state and private universities in Merauke and surrounding areas. The hope, the more smart city research center spread across several universities / PTS, the development of smart city Merauke will be more rapidly. The realization of Smart City Merauke is very important for Merauke Regency Government to keep the area sustainable and able to compete with other Regencys in Indonesia. The main thing that must be done to realize Smart City is to form smart city board consisting of 3 (three) working groups which is the destination of smart city of Merauke, smart workshop, smart education, and smart agriculture group.

Smart Tourism based on local wisdom, in its development and development, it is necessary to formulate strategies and targets to be achieved, through meetings or focus group discussions involving academics, business, commercial, local community, and government. Where the Meeting discusses the issues and ideas that support the realization of smart tourism, such as social, cultural-customs, tourist destination portal services, public bandwidth allocation, public transportation timeframe, hotel occupancy availability, tourist information boards, marketing, and commitment from all parties. Merauke Smart Tourism should also be viewed from the side of tourists, can be done through citizen-centric approach or service delivery approach with the point of view of the needs of tourists. Phase in this approach is divided into 3 stages, namely the phase before the tour, the phase during the tour, and the phase after the tour. Where elements assessed are objects and attractions, amenitas, accessibility, supporting facilities and institutional.

Merauke Smart Tourism should also be viewed from the stakeholder side or in this context is the Merauke regency government. The approach used is government / business / community centric, or service provision with priority point of view and government / business / community needs. The government-centric approach is divided into three main focuses: smart destinations, tourism, and smart business ecosystems. Citizen-centric and government-centric approaches used to realize Merauke Smart Tourism, both put forward the application of IT (technology \& information) and supporting devices. With the provision of various ITbased tourism services that facilitate tourists, is expected to improve the positive image of tourism in Merauke regency. The provision of such IT-based services must, of course, involve various sectors and coordination in order to harmonize and no overlap of sectoral interests. ICT infrastructure (technology,information and communication)

Smart Education based on local wisdom, Education development in Merauke Regency is currently one of the best in Papua in particular and in eastern Indonesia in general. This is evident from the image of Merauke which is the goal of continuing education for the people in the region of Papua so that it can be called as Regency Education. Various educational facilities in terms of quantity and good quality of education ensure that teaching and learning activities are among the best in eastern Indonesia. This is indicated by the high interest of the inhabitants from within Merauke, and outside Merauke to send their son or daughter to Merauke. So in the development and development of Merauke smart education, it is necessary to formulate the strategies and targets to be achieved. Meetings or focus group discussions involving academics, business, commercial, community and government should be conducted. The meeting will discuss and produce the exposure of the problem along with ideas that support the realization of Merauke smart education which can consist of accessequalization-cost, population data related to education, detailed information from each PTN / PTS, education and the role of parents in school, culture - customs, and transportation constraints.

The review of Merauke Smart Education when viewed from a community or user perspective, is done through a citizen-centric approach or service delivery approach from the perspective of community needs. Phase in this approach is divided into 3 stages of life cycle, that is phase of birth, phase when become student, and phase when become student. The citizen-centric approach used to realize Merauke Smart Education, put forward the application of IT (technology \& information) and its supporting devices. With the provision of various IT-based education services that facilitate can enable students and students to learn and improve the quality of education. 
Smart Agriculture based on local wisdom, in its development and development, it is necessary to formulate strategies and targets to be achieved, through meetings or focus group discussions involving academics, business, commercial, local communities, and government. The meeting discusses the issues and ideas that support the embodiment of smart agriculture, such as rice availability, rice production, climate, policy, land and water availability, agricultural technology, agricultural tools, transportation of crops, and marketing. Merauke Smart Tourism should also be viewed from the farmers side, can be done through citizen-centric approach or service delivery approach from farmer's point of view. The phase in this approach is divided into 3 phases, ie before farming phase, phase during cultivation, and harvest phase. Secondly, Merauke Smart Agriculture should also be viewed from the stakeholder side or in this context is the Merauke regency government. The approach used is government / business / community centric, or service provision with priority point of view and government / business / community needs. The government-centric approach is divided into 3 main focuses: smart destination (land, marketing, accessibility, infrastructure), smart experience (Agricultural services, and smart business ecosystems, agricultural, institutional industries).

Citizen-centric and government-centric approaches used to realize Merauke Smart Tourism, both put forward the application of IT (technology \& information) and supporting devices. With the provision of various IT-based agriculture services that facilitate farmers and investors, is expected to improve the image of national rice barn in Merauke Regency. The provision of such IT-based services must, of course, involve various sectors and coordination in order to harmonize and no overlap of sectoral interests. In order to achieve Merauke smartcity, several work agendas must be implemented within the next 5 (five) years. Stages of implementation of several work agenda is divided into 2 (two), namely short term with span of 1-2 years ahead, and medium term with period of 3-5 years ahead. Shortterm stages have an urgent or immediate agenda. Two main things that are urgent to be implemented related to Merauke smartcity is, branding smart city of Merauke Regency and institutional study of smart city board of Merauke. The preparation of this branding must coordinate with the Provincial Government of PapuaMRP and and Merauke-LMA Regency to be aligned.

\section{Conclusion}

(1) Branding Smart City The urgent thing that must be done to realize Smart City Merauke is to make branding of Merauke Regency. Branding or city branding can be interpreted as a strategy or process of brand formation of a Regency in various forms of media campaign, to be known by the public. Branding in the context of Smart City Merauke is needed to socialize and increase the motivation to succeed smart city, or simply needed as a spirit to move together.
(2) Synchronization of Merauke Smart City Policy and Strategy Aligning Merauke Smart City policies and strategies is done through synchronization, harmonization and synergy of Merauke Regency policy. The formulation of policies and strategies of Merauke Smart City can be preceded by the preparation of Road Map Merauke Smart City. The Road Map of Merauke Smart City is integrated into the RPJMD of Merauke Regency, so that if policies, strategies, objectives, targets, and programs are included in the Merauke RPJMD, Merauke Smart City initiatives and initiatives can be accommodated in the preparation of the RKPD of Merauke Regency and the related SKPD Strategic Plan. Thus the implementation of Merauke Smart City through programs and activities undertaken by SKPD related can be realized.

(3) Merauke Smart City Element Arrangement The arrangement of Merauke Smart City elements includes smart city institutions, networks, and resources. Institutional arrangements Merauke Smart City should consider organization, regulation, or norms / ethics / culture. Organizational considerations necessary to formulate policies and strategic direction of development and development of Merauke Smart City is Smart City Council of Merauke. Smart City Council Merauke plays a partner of the Government of Merauke Regency (Government-CIO) in the development and development of smart city. The establishment of 'Smart City Board of Merauke' needs to pay attention to budget capacity, roles and support. Merauke Smart City regulations need to be developed primarily on the sharing of ICT resources, funding, documentation, and co-operation / investment guidelines for third parties. Merauke Smart City also needs to pay attention to local norms / ethics / culture based on professionalism. The networking of Merauke Smart City is done through stakeholder interaction and synergy: Academic, Business, Community, Government, Society and Media. Setup of resources Merauke Smart City is done through the arrangement of brainware, software, and hardware. Structuring the brainware should pay attention to expertise, expertise, competence, and skills. Structuring software and hardware needs to pay attention to interoperability, scalability, and reliability.

(4) Development of Merauke Smart City can be done through the commitment and consensus of Merauke Smart City element; potential mapping and analysis of Merauke Smart City, creating alignment between business processes and ICTs using Enterprise Architecture (business processes, systems, technologies, applications, data, human resources, and organizations); management of Merauke Smart City resources (including brainware, software, and hardware); governance (Business, IT (including security), and Process) and management (including change management and risk management) Merauke Smart City; drafting branding (eg Merauke Smart City, Merauke Digital City, Great Merauke, iMerauke, or eMerauke, etc.), Merauke Smart City Living Lab development; the continued development and development of Merauke Smart City. Living Lab Merauke Smart City is a commitment, participation, and 
dedication of PTN / PTS in Merauke in the utilization of ICT for the implementation of Merauke Smart City so that it is expected to improve the governance of Merauke Regency Government better and smarter in providing excellent service in the field of government, society, and development.

(5) with the achievement of increasing use of technology in the development of smart cities in Merauke district, it is expected that with the existing technology can play a role in socializing low-carbon development.

\section{References}

1. Djunaedi, A. Seminar Nasional Smart City: "Solusi untuk Permasalahan Perkotaan Indonesia?". Yogyakarta. (2014).

2. Fritz Akhmad Nuzir \& Ridwan Saifuddin, Smart People, Smart Mobility Konsep Kota Pintar yang Bertumpu pada Masyarakat dan Pergerakannya di Kota Metro, (2015). Available at :https://www.researchgate.net/publication/2816148 90_Smart_People_Smart_Mobility_Konsep_Kota_ Pintar_yang_Bertumpu_pada_Masyarakat_dan_Per gerakannya_di_Kota_Metro/link/55eff14508aef559 dc44f1aa/download

3. Cohen, B. The top 10 smart cities on the planet.https://www.fastcodesign.com/1679127/thetop10-smart-cities-on-the-planet. (2012)

4. Allwinkle, Sam \& Cruickshank, Peter. Creating Smart-er Cities: An Overview. Journal of Urban Technology, Vol. 18, No. 2, April 2011, 1-16. Routledge. (2011).

5. Taewoo Nam \& Theresa A. Pardo. Conceptualizing Smart City with Dimensions of Technology, People, and Institutions, The Proceedings of the 12th Annual International Conference on Digital Government Research, 282-292. (2011). Available at : https://intaaivn.org/images/cc/Urbanism/background\%20docu ments/dgo_2011_smartcity.pdf

6. Griffinger, R., dkk. Smart cities Ranking of European medium-sized cities. Final report October. (2007) 